\title{
ANALYSIS OF ANDROID-BASED MSME ACCOUNTING APPLICATION ON MSME ACTIVITIES IN THE AREA OF EDUCATION FOUNDATIONS AIRMADIDI KLABAT UNIVERSITY
}

\author{
Merry L. Sael, Jeane C. Lasut, Decire D. Wagiu, Harty U. H. L Koagouw. \\ Department Of Accounting, Polytechnic of Manado Country \\ DOI: 10.31364/SCIRJ/v9.i09.2021.P0921874 \\ http://dx.doi.org/10.31364/SCIRJ/v9.i09.2021.P0921874
}

\begin{abstract}
The purpose of this research is to analyze how the application of Android-based MSME accounting to MSME actors in the Education Foundation area of the Universitas Klabat Airmadidi. The research method used by the researcher is a qualitative method with a case study approach that is based on phenomena and is explored logically in accordance with scientific principles. The results show that business actors have not implemented Android-based MSME accounting because they have not received socialization about MSME accounting applications. Business actors in their financial information still use manual records which basically only a small part is recorded. The application of Android-based MSME accounting can help business actors to obtain financial information about their business.
\end{abstract}

Keywords: MSME Accounting, Android Based.

\section{INTRODUCTION}

Micro, small and medium enterprises (MSMEs) have an important role in the Indonesian economy. That is why the government gives high and special attention. Micro, Small and Medium Enterprises can have a direct impact on people's lives in the lower and middle sectors. There are three important roles of Micro, Small and Medium Enterprises in people's lives, namely: First, a means of alleviating the community from poverty, due to the high rate of absorption of labor by MSMEs, as evidenced by the number of MSMEs that are growing at this time, creating job opportunities for businesses. creative. Second. a means to even out the level of the economy, for example, many of the same MSMEs grow in various regions, not even only in urban areas, in rural areas the same types of businesses grow. In contrast to large companies, which only exist in urban areas. Third, provide foreign exchange income for the country. Many of the products produced by MSMEs are not only national in scale. However, it has an international scale so that it can generate foreign exchange. That is why MSMEs are being encouraged by the government to improve the Indonesian economy.

The Indonesian economy had slumped due to the COVID-19 pandemic, and MSMEs were no exception. But currently, the government is carrying out a National Economic Recovery starting from the MSME sector, because this sector contributes $61 \%$ of the Gross Domestic Product (GDP) in Indonesia. The government hopes that MSMEs can play a role in building the national economy. even micro, small, and medium enterprises. This is a driving force for the rise of the national economy, MSMEs are also included in the development of regional potential-based and market-oriented businesses, so that a balanced economic structure will be created, including creating employment opportunities, income distribution, economic growth, and overcoming poverty.

The role of MSMEs in improving the community's economy is clearly seen where many forms of MSMEs have sprung up and are trying to rise. However, the existing MSMEs, it turns out that many cannot develop due to lack of capital, lack of knowledge of financial information management, lack of ability to compete, lack of relationships and so on. However, the most influential is the lack of ability in managing financial information, the influence of financial information in a business can make the business grow or not. Until now, the problems commonly faced by MSMEs are in managing their financial information, limited knowledge of accounting is a factor that causes many MSMEs to fail to develop their businesses. In his research (Birawani, 2015) the variables used to determine the factors of financial management are financial records, budgets and other financial skills. In the research of Sari \& Setyawan (2012), it was found that some MSMEs have not managed their finances properly because they feel that their business is still too small, and there are various difficulties. The ability to manage financial information is the most dominant factor in the failure of an MSME to develop (Wardi, Liviawati \& Wiyati, 2018). To be able to survive during the COVID-19 pandemic, MSME actors also need to be careful in managing finances and spending efficiently in the hope of maximizing business financial performance. With good financial information having a positive effect on financial 
performance, it will also result in good company performance (Suindari \& Juniariani, 2020). The inability of MSMEs to provide good financial reports will have an impact on the inability of investors and creditors in assessing the financial performance of MSMEs.

To overcome the inability and lack of knowledge about the management of financial information, currently there are solutions for MSME actors who often find it difficult to do good financial reporting. Digitization is a potential for MSMEs to provide convenience for recording financial transactions with the emergence of various android-based accounting applications. The advantages of android-based applications are that they are easy to install and easy to operate so that they can produce financial information needed by MSMEs. But the problem is, do MSME actors know the Android-based MSME accounting application? How is the application of MSME accounting by MSME actors? Based on the above background, the research team is interested in researching with the topic "Analysis of Android-Based MSME Accounting Applications for MSME Actors in the Education Foundation Area of Universitas Klabat Airmadidi." Where the place of this research is a place for growth and gathering of MSME actors. Because this area is very promising. The Klabat University Education Foundation area is a place for education ranging from kindergarten, elementary, junior high, high school and university, so this area becomes a gathering place for people who are not only from the North Minahasa area, but from other provinces in Indonesia. Based on this background, the researchers formulated the problem, namely "How is the application of Android-based MSME accounting to MSME actors in the Education Foundation Area of Universitas Klabat Airmadidi?

\section{RESEARCH METHODS}

The method used in this research is a qualitative approach which is based on phenomena and is explored logically in accordance with scientific principles. This study uses a case study method developed by Yin (1986). This approach is to explain how the application of MSME accounting to MSME actors in the Klabat Airmadidi University Area with regard to "how", "why", and "what". According to Yin (1996; 8-13) the case study method is based on considerations 3 conditions are:

1. This research is to answer the questions "how", "why" or "what" contained in the formulation of the problem

2. Researchers cannot regulate, control or influence the object of research

3. This research is focused on contemporary events

In this study, researchers used data collection techniques, namely:

1. Observation or field research, namely direct observation data collection techniques, on the object of research that aims to observe how the application of Android-based MSME accounting by MSME actors in the Klabat Airmadidi University Education Foundation Area.

2. Interviews were conducted on MSME actors in the Klabat University Foundation Area related to the application of androidbased accounting.

In analyzing the data in this study, the researchers used a case study technique by presenting the results of interviews with MSME actors. From the results of direct interviews with data reduction, namely concluding the data taken about the application of MSME accounting to business actors in the area that is the object of this research.

Several stages were carried out by researchers carrying out this research, namely:

1. Preliminary survey of the object of research, namely business actors.

2. Preparation of research instruments related to the problem under study

3. Conducting interviews with related parties such as micro business actors with research problems.

4. Collecting data - supporting data.

5. Analyzing primary and secondary data obtained in a specified manner.

6. Compile the final report

\section{DISCUSSION}

\subsection{Overview of MSMEs in the Education Foundation Area of Universitas Klabat Airmadidi}

The Klabat University Education Foundation area is located in the valley of Mount Klabat, Airmadidi Bawah, Airmadidi sub-district, North Minahasa Regency, North Sulawesi Province. The location of the Klabat University Education Foundation Area is very strategic to say that it is a promising area for MSME business actors because it is very easy to reach, and is a meeting place for many people who have an interest in bringing their children to education starting from kindergarten, elementary school. , Junior High School, Airmadidi Unklab High School and Klabat University College

In accordance with the results of a survey of student data at the Foundation, it is estimated that around 5,000 people come from various regions, different backgrounds and ethnicities, and coupled with the population living in the area can be said to be very dense, so that business actors are very interested to open a business in this area. They open businesses according to different types and forms of business, with different characteristics and skills, ranging from restaurants, boarding houses, photocopies, hairdressers, tailors, drinking water depots, fruit sellers, sellers. fries and others. Then, this is where business actors compete with each other to advance or develop their business even in the midst of the COVID-19 pandemic.

\subsection{Analysis of MSME Accounting Applications for MSME Actors in the Education Foundation Area of Universitas Klabat Airmadidi}

The COVID-19 pandemic is still endemic today, so various government policy rules have been set to reduce its spread, including the imposition of restrictions on community activities. Rules for the Implementation of Restrictions on Community 
Activities, which limit community activities, have resulted in the delay of face-to-face activities that were previously planned, both from educational activities and other activities, resulting in a decline in the economy of MSME business actors in the Klabat Airmadidi University Education Foundation Area, many of whom did not survive so that it temporarily closes its business. However, there are also SMEs who are trying to get up and survive.

So far, the Indonesian government has tried to control the economy by making policies that can revive an economy that is starting to dim. One of the government policies is the protection and recovery policy for MSMEs.

Policies related to MSMEs during the COVID-19 pandemic, one of which is as a recipient of government social assistance. In addition, the government also has special policies for MSMEs to be able to overcome economic pressures as a result of the Covid 19 pandemic. Among other things, MSME loan restructuring, namely relaxation of asset quality assessments, and delays in principal and interest subsidies and working capital, namely low-interest working capital loans. However, to get the working capital, it is certain that business actors know the business prospects they have, the right financial information, so that the low-interest working capital will be right on target, so that the economy will bounce back.

Business prospects and appropriate financial information are often obstacles for MSME actors in the Klabat University Education Foundation Area, where these actors have limited knowledge to prepare appropriate financial reports. Generating accurate financial reports requires money to pay for competent human resources, and this is what causes these business actors to be unable to develop their businesses.

Currently, technology has been developed that can help MSME actors to produce financial reports through an android application, namely the MSME accounting application, where Android has been owned by every business actor and the advantages of Android-based applications are that they are easy to install, and easy to operate so that they can produce financial information. needed by Micro, Small and Medium Enterprises.

Penelitian ini bertujuan untuk menganalisis penerapan aplikasi akuntansi UMKM berbasis android bagi para pelaku usaha UMKM yang ada di Kawasan Yayasan Pendidikan Universitas Klabat Airmadidi. Hasil penelitian menunjukkan bahwa penerapan aplikasi akuntansi UMKM belum diterapkan oleh karena kurangnya sosialisasi tentang aplikasi akuntansi UMKM berbasis android.

According to Mr. Made, a laundry business actor "Agung Laundry", said that this application had never been heard of and lacked socialization, so its application had not been implemented. Even though the business he is engaged in is still running even during the covid 19 pandemic. The results of the interview obtained that income data from Agung Laundry ranged from IDR. 600,000 - IDR. 1,500,000 per day. With various categories of service types, such as IDR. 2,500/Kg wet laundry, IDR. $6,000 / \mathrm{kg}$ dry folding laundry, and IDR. 7,500 laundry iron.

Besides Mr. Made, there is also Mrs. Rilan who has a sewing business, whose daily income is around IDR 150,000 - IDR 600,000 per day. His sewing business has survived during the covid pandemic, and has never tried to apply for a soft loan due to limited knowledge of the requirements that must be submitted and the absence of financial information for the business being carried out. Their financial records look very simple, especially because they are not knowledgeable in making financial reports, so it is very difficult to apply MSME accounting applications

According to Mr. Jem, the owner of a food stall, the implementation of daily financial activities is only recorded manually, because to produce proper financial reports it costs money to pay for competent human resources in this field. According to him, the cost is very large compared to the income. And hearing the MSME accounting application, they are very enthusiastic about implementing Android-based accounting if given training.

Several other business actors who were interviewed said that making financial reports was very difficult. In addition, business actors do not know the benefits of financial reports for them, because for them to maintain this business it is more important to think about than to make financial reports. Even these micro-enterprises have not been able to distinguish good financial reports for small-scale business actors as they are currently running

To be able to produce financial statements, it is done with the accounting cycle starting from recording journals, posting to the general ledger, trial balance, making adjusting journals and making financial reports. There are 3 financial reports for MSMEs, namely the income statement, the statement of financial position and the notes to the financial statements, for that, competent resources are needed.

Currently there are several applications that can help MSME business actors to be able to produce financial reports, without using the services of competent experts, because to produce financial reports can be through Android owned by every business actor. To overcome the inability and lack of knowledge about the management of financial information, currently there are solutions for MSME actors who often find it difficult to do good financial reporting. Digitization is a potential for MSMEs to provide convenience for recording financial transactions with the emergence of various android-based accounting applications. Currently, there are several applications that can help MSME business actors to be able to produce financial reports without using the services of competent experts, because to produce financial reports you can use Android owned by every business actor. The advantages of android-based applications are that they are easy to install and easy to operate so that they can produce financial information needed by MSMEs.

The large need for MSMEs to provide quality financial reports, while still taking into account the cost and efficiency factors, has led to many developing applications or services for accounting system providers, both computer-based and cloudbased. There are many accounting applications currently available, some are cloud computing-based, and some are desktop-based. Desktop-based accounting software or applications are accounting software that stores databases in local storage. While cloud computing-based accounting software is accounting software that stores databases and computations on cloud servers or the internet (Anitasari, 2017). While the accounting application that is the focus of this research is accounting software that can be run on smartphones, both desktop-based and cloud computing.

\section{WwW.scirj.org}

(C) 2021, Scientific Research Journal

http://dx.doi.org/10.31364/SCIRJ/v9.i09.2021.P0921874

This publication is licensed under Creative Commons Attribution CC BY. 
If every business actor applies Android-based MSME accounting, it will have an impact on the development of the business they run. The development of the business carried out will be assisted by the trust of the government and other financial institutions in terms of providing capital assistance and soft loans for every business actor. And the benefits that can be felt by MSME business actors if applying Android-based MSME accounting are 5, namely:

1. Business Actor can convey useful information for business planning

2. Business actors can find out the financial position of the business

3. Business actors can provide an overview of the company's profit/loss

4. Business actors can simplify the calculation of business taxes that need to be reported

5. Business actors can provide data information regarding business performance

By implementing Android-based MSME accounting, MSME actors are also careful in managing finances and spending efficiently in the hope of maximizing business financial performance. With good financial information, it will have a positive effect on financial performance, and will also result in good business performance

\section{CONCLUSION}

The Manado State Polytechnic Team in this research activity, focused on the application of Android-based MSME accounting, to MSME actors in the Education Foundation area of the Klabat Airmadidi University, the following conclusions can be drawn

1. Business actors have not implemented Android-based MSME accounting. Basically, these business actors have not received socialization about MSME accounting applications.

2. Business actors in their financial information still use manual records which basically only a small part is recorded.

3. The application of Android-based MSME accounting can help business actors obtain financial information about the businesses they run.

4. This research encountered a few obstacles due to the COVID-19 pandemic.

\section{REFERENCES}

Anita Ria. 2018. Analisis Analysis of the Application of Android-Based Financial Applications. https://e-jounal.ipp munindra.ac. Hetika,et al. 2020. Android Based Accounting Application. https:e journal.poltektegal .ac.id .monex article

Ikatan Akuntansi Indonesia. (2018). Financial Accounting Standards, Micro Small and Medium Entities Jakarta.

INDONESIA), 1. (. (2018). Financial Accounting Standards for Micro, Small and Medium Entities. Jakarta: Indonesian Institute of Accountants Financial Accounting Standards Board.

Ikatan Akuntan Indonesia. (2015). Financial Accounting Standards. Jakarta: Salemba Empat

Ibrahim. 2015. Qualitative Research Methodology. Bandung: Alfabeta, CV.

Jemes M. Reeve. 2013. Introduction to Indonesian Adapted Accounting. Jakarta. Salemba empat.

Kieso, D. E., Weygandt, J., and Warfield,T.D. 2011. Intermediate Accounting IFRSEdition. New Jersey. John Wiley \& Sons Inc

Luh Putu Windayani.2019. Android-Based Accounting Implementation Analysis .https://ejournal.undisha.ac.id>article

Sugiyono, 2009, Quantitative, Qualitative and R\&D Research Methods, Bandung : Alfab 